\title{
Inverse correlation between Tax and CD25 expressions in HTLV-1 infected CD4 T-cells in vivo
}

\author{
Kenta Tezuka, Runze Xun, Mami Tei, Takaharu Ueno, Masakazu Tanaka, Norihiro Takenouchi, Jun-ichi Fujisawa* \\ From 15th International Conference on Human Retroviruses: HTLV and Related Viruses \\ Leuven and Gembloux, Belgium. 5-8 June 2011
}

Tax has pleiotropic actions that induce proliferation and inhibit apoptosis of T-cells and thus is considered to play a critical role in leukemogenesis. However, Tax expression is frequently lost in fresh adult T-cell leukemia (ATL) cells by genetic changes or epigenetic modifications of proviral genome. To clarify the significance of tax gene in leukemogenesis, we analyzed the expression of tax gene in the HTLV-1 infected human CD4+ Tlymphocytes in humanized mouse system.

NOG-SCID mouse were transplanted with human hematopoietic stem cells and infected with HTLV-1 in vivo by peritoneal injection of MT-2 cells after 4 months of transplantation. HTLV-1 infection induced the rapid proliferation of $\mathrm{CD} 4+\mathrm{T}$-cells, irrespective of the expression of $\mathrm{CD} 25$, and resulted in the severe splenomegaly with CD25+ CD4+ T-cells. Tax gene expression was low in the isolated splenocytes but greatly increased by the ex vivo culture for 24 hours as seen in infected peripheral blood T-cells from HTLV-1 carrier. As the gene expression of CD25 was also activated in proportion to the tax induction, function of Tax was indicated to be responsible for the CD25 expression.

When CD4+ T-cells from HTLV-1 infected splenocytes were separated into CD25+ and CD25- cells, however, tax expression was observed mainly in CD25- CD4 $+\mathrm{T}$-cells. These results indicate that the expression of CD25 may not necessarily involve the Tax function in vivo. We will discuss the function of Tax in CD25- CD4 $+\mathrm{T}$-cells and a significance of CD25 expression without the action of Tax in vivo.

Published: 6 June 2011

* Correspondence: fujisawa@takii.kmu.ac.jp

Dept. Microbiology, Kansai Medical University, Moriguchi, Osaka, 570-8506, Japan
doi:10.1186/1742-4690-8-S1-A14

Cite this article as: Tezuka et al:: Inverse correlation between Tax and CD25 expressions in HTLV-1 infected CD4 T-cells in vivo. Retrovirology 2011 8(Suppl 1):A14.
Submit your next manuscript to BioMed Central and take full advantage of:

- Convenient online submission

- Thorough peer review

- No space constraints or color figure charges

- Immediate publication on acceptance

- Inclusion in PubMed, CAS, Scopus and Google Scholar

- Research which is freely available for redistribution

\section{() Biomed Central}

\section{Biomed Central}

